\title{
COMMENT
}

\section{Long-term changes in the diel vertical migration behaviour of Calanus finmarchicus in the North Sea are unrelated to fish predation}

\author{
Andrew G. Hirst ${ }^{1, *}$, Sonia D. Batten ${ }^{2}$ \\ ${ }^{1}$ George Deacon Division, Southampton Oceanography Centre, Empress Dock, Southampton SO14 3ZH, United Kingdom \\ ${ }^{2}$ Sir Alister Hardy Foundation for Ocean Science, Citadel Hill, Plymouth PL1 2PB, United Kingdom
}

Much effort is presently expended in attempting to understand more fully the dynamics of pelagic communities and the role of phytoplankton, zooplankton and fish. Long-term changes in communities may be a particularly enlightening way of determining the interactions which occur, and may be useful for predicting the consequences of environmental change. Recently, examinations of long-term changes of diel vertical migration behaviour of the calanoid copepod Calanus finmarchicus (copepodite stages C5 and C6) were completed by Hays (1995) and Hays et al. (1996) using data from over 3 decades, collected by the Continuous Plankton Recorder (CPR) survey in the North Sea. The results of their studies appeared to demonstrate that the diel vertical migration of this important zooplankton species was correlated with the biomass of the herring Clupea harengus, a species for which a major component of their diet may be late stage C. finmarchicus (Last 1989). While herring stocks declined from 1960 to the mid 1970s, and then increased until 1990, C. finmarchicus (C5 and C6) appeared to demonstrate a decrease in the time spent in surface waters from the 1960 s to the mid 1970s, and an increase until the 1990s. It was suggested that this copepod avoided predation from herring by avoiding surface waters during the day in years when this visual predator was more abundant. Such a large scale, long-term pattern in behavioural change would have important implications for our understanding of fisheries and zooplankton behaviour and dynamics. We will show, however, that the results and conclusions are based on an unsuitable test, and are unfounded.

\footnotetext{
·E-mail:a.hirst@soc.soton.ac.uk
}

Previously the formula used to quantify diel vertical migratory activity by Hays (1995) and Hays et al. (1996) was of the form:

$\mathrm{N} / \mathrm{D}_{\text {ndex }}=\operatorname{antilog}\left[\right.$ mean $\log \left(\mathrm{n}_{\text {night }}+1\right)-$ mean $\left.\log \left(\mathrm{n}_{\text {day }}+1\right)\right]$

where $\mathrm{n}_{\text {nigh }}$ and $\mathrm{n}_{\mathrm{day}}$ are the number of individuals per sample for samples collected between midnight $\pm 6 \mathrm{~h}$ and midday $\pm 6 \mathrm{~h}$ respectively. The results from this equation when compared against total herring stock demonstrated a regression with significant correlation. Unfortunately the method chosen by Hays (1995) and Hays et al. (1996) is flawed in 2 important ways. Firstly, using a constant definition of day and night which does not consider seasonality results in gross error. Many winter collected samples were defined by Hays as 'day' collected when they were sampled after sunset but before sunrise, conversely many summer collected samples were formerly defined as 'night' samples but were in fact collected during daylight hours. We find that in any one year up to $40 \%$ of individuals defined as being sampled at 'night' were collected during daylight hours in the summer, and up to $40 \%$ of the 'day' assigned ones were collected during the night-time. Given that upward migration activity generally occurs at or around sunset, and descent prior to sunrise (Huntley \& Brooks 1982), it is important for this allocation to be accurate.

The second problem associated with the index derived by Hays (1995) and Hays et al. (1996) is its sensitivity to the absolute abundance of organisms. The same relative proportion of individuals collected at night to the day will give a greater $N / D_{\text {index }}$ value if absolute abundance is greater. To give an example, when $n_{\text {night }}=20$, and $n_{\text {day }}=10$ an index value of 1.909 is derived, while when $n_{\text {night }}=2$, and $n_{\text {day }}=1$, the value 
becomes 1.5. The only scenario when the index is insensitive to absolute abundance is when day and night-time values are equal. Given that there are large shifts in the abundance of Calanus finmarchicus in the study area over the period investigated here then the use of an abundance dependent index is potentially misleading. In the present investigation we re-analyse the diel vertical migration of $C$. finmarchicus correcting for these 2 highlighted errors, day-night definition and abundance dependence in the index itself.

In our study we examine the same copepod data set from the CPR records, and herring total biomass data (Anonymous 1995). We describe migration using the actual times of sunset and sunrise defined at the midpoint of the area $\left(57^{\circ} \mathrm{N}, 3^{\circ} 30^{\prime} \mathrm{E}\right)$ on the middle day of each month. Samples were then allotted to $n_{\text {night }}$ if collected between the times of sunset and sunrise, and to $\mathrm{n}_{\text {day }}$ if collected between sunrise and sunset. Diel vertical migration (DVM) was also examined using an index which is independent of abundance, given as:

$$
\text { DVM }=\left[\text { mean } \sqrt[4]{n_{\text {night }}} /\left(\text { mean } \sqrt[4]{n_{\text {nught }}}+\text { mean } \sqrt[4]{n_{\text {day }}}\right)\right]^{4}
$$

This index gives a value of 0.0625 when there is no migration, i.e. no difference in mean daytime and mean night-time abundance regardless of absolute abundance. Presence of individuals during the night but complete absence during the day gives a value of 1.0, while complete absence during the night and presence during the day give a value of zero. Fourth root transformations were used to compress the data (as is common practice for this highly variable data) while avoiding problems associated with logarithmic transformation given that the data set includes many zero values.

Results derived using Hays' definitions of day and night and our sunset-sunrise definition of day and night were examined separately for each of the diel migration indices, i.e. $N / D_{\text {Index }}$ and DVM. Association was tested by completing linear regression of index results versus total herring biomass, and productmoment correlation analysis was used to test for signif-

icance. In all cases the regressions were tested for normality and homoscedasticity and passed $(p>0.05)$.

Our results from using both indices and both definitions of day and night are presented in Table 1. Linear regression with subsequent correlation coefficient for each of the indices against the total herring biomass in North Sea in both cases give significant results using the Hays definition of day and night $(p<0.001)$. The $\mathrm{N} / \mathrm{D}_{\text {index }}$ results were more highly correlated to herring biomass $\left(\mathrm{r}^{2}=0.407 ; \mathrm{n}=37\right)$ than DVM $\left(\mathrm{r}^{2}=0.314 ; \mathrm{n}=\right.$ 37). Using the abundance dependent index resulted in greater correlation because Calanus abundance and herring biomass co-vary to some extent, as such there is some bias in the $N / D_{\text {index }}$ results. However, neither index gives a significant relationship against herring total biomass using our sunset-sunrise definition of day and night ( $p>0.05$ for $N / D_{\text {indexi }} p>0.10$ for $D V M$ ). Once again the DVM results are slightly less significant than the $N / D_{\text {index }}$, using an abundance dependent index brings about an increase in the significance of the correlation.

Given that much of the apparent significance in the correlation between diel migration and herring stock results from the definition of day and night it is instructive to examine this in more detail. Fig. 1 demonstrates the $N / D_{\text {index }}$ and DVM values derived using the 2 definitions of day and night. For each index results diverge most as a result of day-night definition before 1970 , and this results in most of the loss in correlation between index results and herring biomass. From the 1950 s to the 1970 s Calanus finmarchicus abundance in the summer was particularly elevated, however, many of the high abundance values were classified by Hays as 'night' collected when they were actually collected during daylight hours, subsequent correction to our sunset-sunrise definition results in a reduction in the diel migration indices; both indices give lower values when day abundance increases with respect to those at night, and also lower values when migration is reversed (i.e. day abundance is greater than that at night). Corrections through much of the period after 1970 resulted in less change in the diel

Table 1. Results from linear regression and correlation analysis of diel migration index results versus herring total biomass in the North Sea, applying both indices and both definitions of day and night. Sunset-sunrise defined here as actual times of sunset and sunrise at the mid-point of the area $\left(57^{\circ} \mathrm{N}, 3^{\circ} 30^{\prime} \mathrm{E}\right)$ on the middle day of each month. In all cases $n=37$. ns: not significant

\begin{tabular}{|c|c|c|c|}
\hline $\begin{array}{l}\text { Diel vertical } \\
\text { migration index }\end{array}$ & $\begin{array}{l}\text { Definition of } \\
\text { day and night }\end{array}$ & $\begin{array}{l}\text { Regression } \\
r^{2}\end{array}$ & $\begin{array}{c}\text { Significance } \\
\text { level }\end{array}$ \\
\hline $\mathrm{N} / \mathrm{D}_{\text {Index }}$ & $\begin{array}{l}\text { Midday } \pm 6 \mathrm{~h} \text {, midnight } \pm 6 \mathrm{~h} \\
\text { Sunrise-sunset }\end{array}$ & $\begin{array}{l}0.407 \\
0.085\end{array}$ & $\begin{array}{l}p<0.001 \\
p>0.05 n s\end{array}$ \\
\hline DVM & $\begin{array}{l}\text { Midday } \pm 6 h \text {, midnight } \pm 6 h \\
\text { Sunrise-sunset }\end{array}$ & $\begin{array}{l}0.314 \\
0.062\end{array}$ & $\begin{array}{l}p<0.001 \\
p>0.10 n s\end{array}$ \\
\hline
\end{tabular}

migration indices because although misdefinition of day and night was as common, abundance values were relatively lower; shifts between night and day allocation therefore resulted in less change in the diel migration index.

In our study we demonstrate that, contrary to previous suggestions of Hays (1995) and Hays et al. (1996), patterns in the changes in the diel migration of Calanus finmarchicus in the North Sea do not co-vary with the biomass of herring. We show that in previous analysis errors 

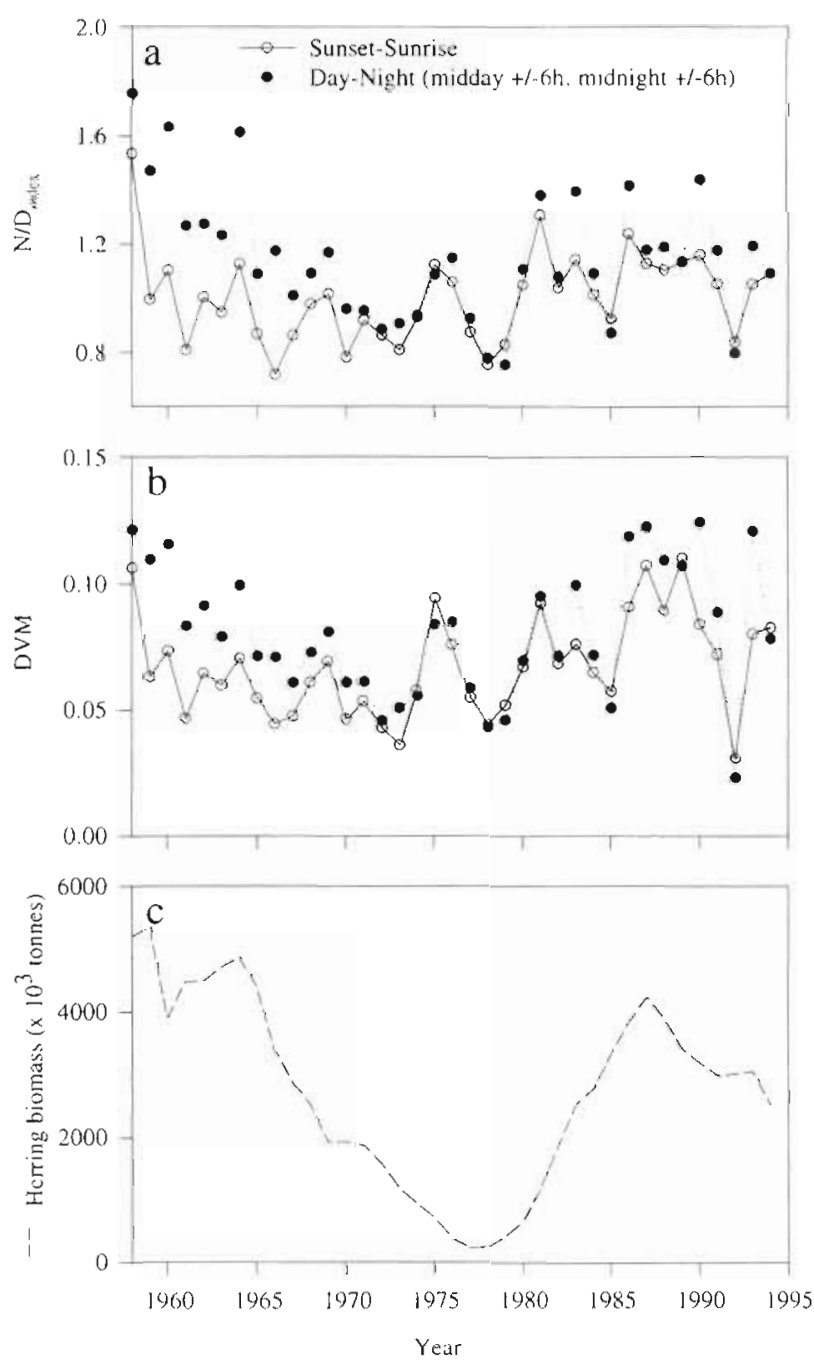

Fig. 1. (a) $N / D_{\text {index }}$ values and (b) DVM values for Calanus finmarchicus (C5 and $\mathrm{C} 6$ ) in the North Sea $\left(54^{\circ}\right.$ to $60^{\circ} \mathrm{N}, 3^{\circ} \mathrm{W}$ to $10^{\circ} \mathrm{E}$ ) calculated using the Hays (1995) and Hays et al. (1996) definition of day and night (midday $\pm 6 \mathrm{~h}$; midnight $\pm 6 \mathrm{~h}$ ), and our sunset-sunrise definition (see text for details). (c) Herring total biomass in the North Sea (south of $62^{\circ} \mathrm{N}$ ) for the period 1958 to 1994

are associated with using an index which is abundance dependent, although more importantly errors result from inaccurate definition of day and night. Given our findings the more extensive analysis on migration of many copepod species presented in Hays et al. (1996) using the same erroneous methods is now thrown into serious doubt.

Diel vertical migration by the congeneric copepod Calanus pacificus has previously been found to be modified by the availability of food (Dagg et al 1997), with individuals staying in surface waters more in periods when food is less abundant (Huntley \& Brooks 1982). Huntley \& Brooks (1982) described how unusual daytime surface swarms of Calanus have been observed during periods when food may be in short supply, for example in temperate zones after the spring bloom (in the studies of Brook 1886, Bigelow 1926, Marshall \& Orr 1927, Russell 1928). In these cases hunger apparently overrides the usual migration patterns. Huang et al. (1993) found that Calanus sinicus ( $\mathrm{C} 5$ and $\mathrm{C} 6$ ) in the Inland Sea of Japan demonstrated an increasing amplitude of diel migration, i.e. the difference between day and night median depths, when food in surface waters increased relative to that at depth. Dagg (1985) found that well-fed Neocalanus plumchrus individuals undergo diel vertical migration more intensely than those which are food-limited. To explore possible interactions in the North Sea we have calculated the arithmetic mean annual phytoplankton colour measurements for the North Sea (as completed by CPR survey for the same area of the North Sea $\left(54^{\circ}\right.$ to $60^{\circ} \mathrm{N}, 3^{\circ} \mathrm{W}$ to $10^{\circ} \mathrm{E}$ ) as a proxy of food available to Calanus finmarchicus. A linear regression of DVM against the phytoplankton colour is insignificant, but only marginally so $\left(\mathrm{r}^{2}=0.087 ; \mathrm{p}=0.077 ; \mathrm{n}=37\right)$.

To some extent the lack of a significant relationship between diel migration and the abundance of the predator herring in our study may have resulted from large scales over which data has been averaged. In localised areas there is evidence that migration of marine copepods may be related to predation, for example diel vertical migration by Calanus pacificus was found to change in response to the abundance of visually orienting predators in a temperate fjord (Bollens \& Frost 1989). We suggest that future analysis should explore migration processes at higher spatial and temporal resolutions. Such analysis may also prove fruitful with regard to the abundance or biomass of phytoplankton.

\section{LITERATURE CITED}

Anonymous (1995) Report on the herring assessment working group for the area south of $62^{\circ} \mathrm{N}$. CM-ICES 1995/ Assess: 13

Bigelow HB (1926) Plankton of the offshore waters of the Gulf of Maine. Bull Bur Fish Wash 60:1-509

Bollens SM, Frost BW (1989) Zooplanktivorous fish and variable diel vertical migration in the marine planktonic copepod Calanus pacificus. Lumnol Oceanogr 34: 1072-1083

Brook G (1886) Report on the herring fisheries of Loch Fyne and the adjacent districts during 1885. Rep Fish Bd Scotl $4: 47-61$

Dagg MJ (1985) The effects of food limitation on diel migratory behaviour in marine zooplankton. Arch Hydrobiol 21. $247-255$

Dagg MJ, Frost BW, Newton JA (1997) Vertıcal migration and feeding behaviour of Calanus pacificus females during a phytoplankton bloom in Dabob Bay, U.S. Limnol 
Oceanogr 42:974-980

Hays GC (1995) Zooplankton avoidance activity. Nature 376: 650

Hays GC, Warner AJ, Lefevre D (1996) Long-term changes in the diel vertical migration behaviour of zooplankton. Mar Ecol Prog Ser 141:149-159

Huang C, Uye S, Onbé T (1993) Ontogenetic diel vertical migration of the planktonic copepod Calanus sinicus in the Inland Sea of Japan. III. Early summer and overall seasonal pattern. Mar Biol 11.7:289-299

Huntley M, Brooks ER (1982) Effects of age and food avail- ability on diel vertical migration of Calanus pacificus. Mar Biol 71:23-31

Last JM (1989) The food of the herring, Clupea harengus, in the North Sea, 1983-1986. J Fish Biol 34:489-501

Marshall SM, Orr AP (1927) The relation of the plankton to some chemical and physical factors in the Clyde Sea area. J Mar Biol Assoc UK 14:837-868

Russell FS (1928) The vertical distribution of marine macroplankton. VII. Observations on the behaviour of Calanus finmarchicus in relation to light intensity. J Mar Biol Assoc UK 15:429-454

\title{
Erratum
}

\section{Particle size selectivity and resource partitioning in five species of Thalassinidea (Crustacea: Decapoda)}

\author{
Eunice H. Pinn, R. James A. Aikinson, Andrew Rogerson
}

Mar Ecol Prog Ser 169: 243-250, 1998

- The comma after 'James' in the list of author names on the title page was incorrect. The second author's correct full name is 'R. James A. Atkinson' 